\title{
Gallstone ileus: a not-so-rare cause of bowel obstruction in the elderly
}

\author{
Anthony 0 Noah, Ashar Wadoodi, Oliver Priest
}

Department of Surgery, Maidstone \& Tunbridge Wells NHS Trust, Maidstone, UK

Correspondence to Dr Anthony 0 Noah, anthony.noah@gmail.com

\section{DESCRIPTION}

A 92-year-old lady presented to the emergency department with a 2-day history of generalised colicky abdominal pain, diarrhoea and vomiting. Her medical history included gallstones and a right hemicolectomy for a benign caecal neoplasm in 2008. Abdominal palpation revealed suprapubic tenderness with no peritonism. Initial investigations included a white cell count of $12.5 \times 10^{9} / 1$, C-reactive protein of $46 \mathrm{mg} / \mathrm{l}$ and a normal serum amylase of $76 \mathrm{U} / \mathrm{dl}$. Plain abdominal x-ray was within normal limits. She was treated for gastroenteritis, but her condition deteriorated over the next $24 \mathrm{~h}$ with intractable vomiting, abdominal distension and ongoing pain. Repeat abdominal radiograph showed dilated stomach, dilated small bowel and an abnormal air pattern in the right upper quadrant. Contrast-enhanced CT scan revealed small bowel dilatation and a large concentric calcified object in the small bowel (figure 1) indicative of gallstone ileus. She underwent successful laparotomy and small bowel enterotomy to remove the stone (figure 2).

Gallstone ileus is a rare cause of bowel obstruction, accounting for $1-3 \%$ of all intestinal obstructions. It is more common in women and in the elderly, accounting for up to $25 \%$ of small bowel obstructions (SBO) in those over 65 years. ${ }^{1}$ Gallstone ileus occurs when a large

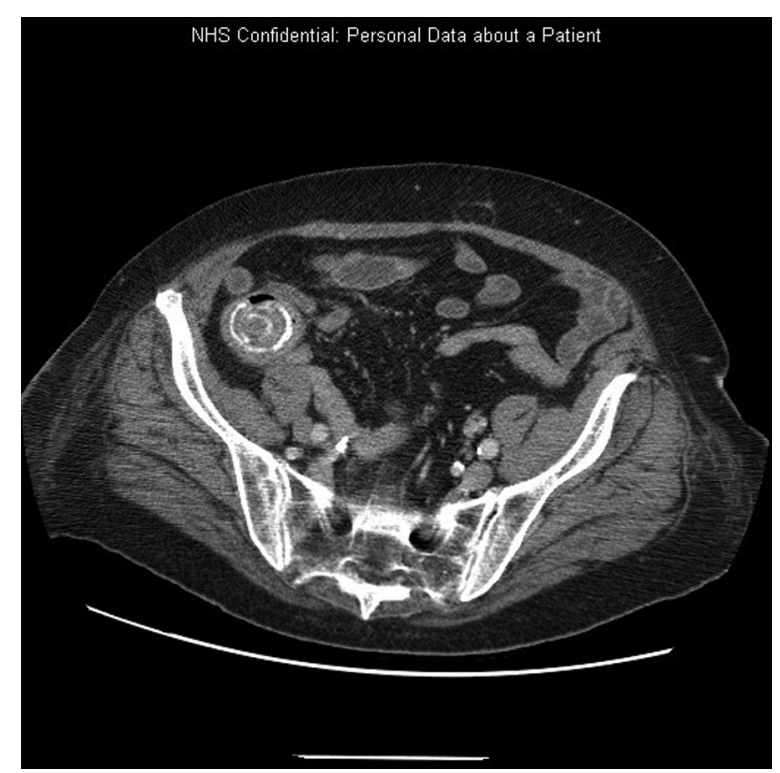

Figure 1 CT scan at the level of the pelvis showing a large calcific gallstone in the small bowel.

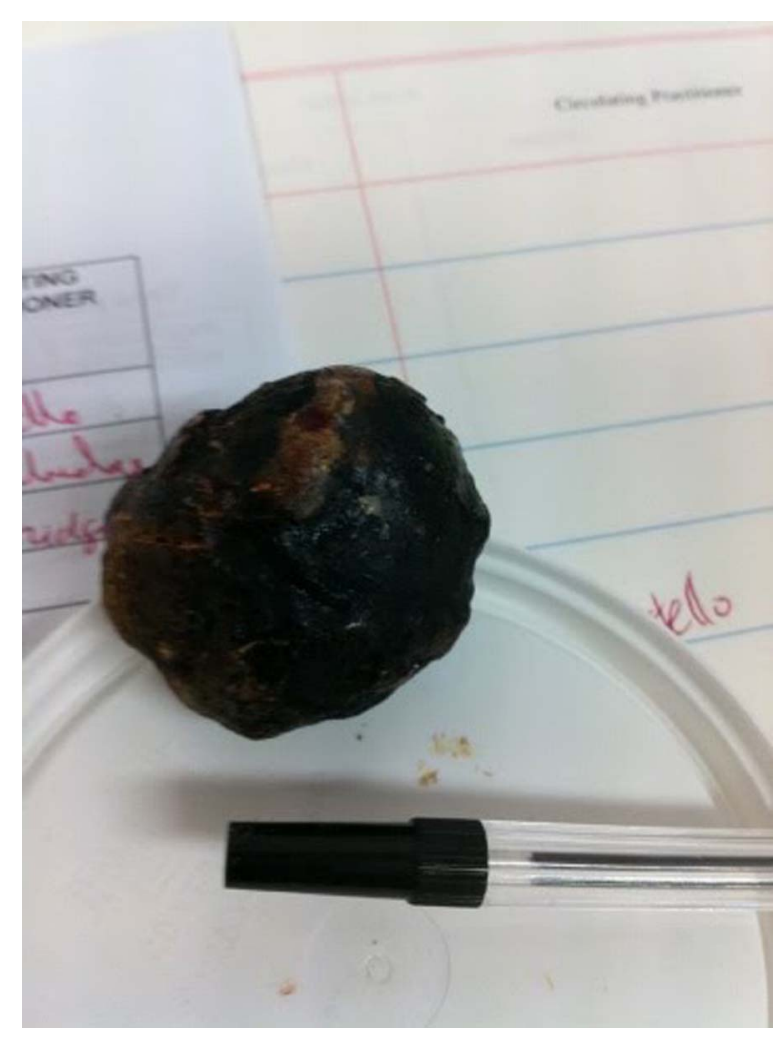

Figure 2 Postoperative image of the gallstone adjacent to a pen for scale comparison.

gallstone ( $>2.5 \mathrm{~cm}$ diameter) erodes through a gangrenous gallbladder into the small bowel and impacts in the smalldiameter distal ileum where peristalsis is less active. Plain $\mathrm{x}$-ray is non-specific as only $10-20 \%$ of gallstones can be visualised with this modality. One study observed Rigler's triad of SBO, pneumobilia and ectopic gallstone within the bowel in $15 \%$ of $x$-rays and $77 \%$ of CT scans. ${ }^{2}$ Treatment is with surgical removal of the stone, combined with cholecystectomy and fistula repair in a number of highly selected cases. ${ }^{3}$

Competing interests None.

Patient consent Obtained.

\section{REFERENCES}

1. Kirchmayr W, Muhlmann G, Zitt M, et al. Gallstone ileus: rare and still controversial. ANZ J Surg. 2005;75:234-8. 


\section{BMJ Case Reports}

2. Lassandro F, Gagliardi N, Scuderi M, et al. Gallstone ileus analysis of radiological findings in 27 patients. Eur J Radiol. 2004;50:23-9.
3. Doko M, Zovak M, Kopljar M, et al. Comparison of surgical treatments of gallstone ileus: preliminary report. World J Surg 2003;27:400-4.

Copyright 2012 BMJ Publishing Group. All rights reserved. For permission to reuse any of this content visit http://group.bmi.com/group/rights-licensing/permissions.

BMJ Case Report Fellows may re-use this article for personal use and teaching without any further permission.

Please cite this article as follows (you will need to access the article online to obtain the date of publication).

Noah A0, Wadoodi A, Priest 0. Gallstone ileus: a not-so-rare cause of bowel obstruction in the elderly. BMJ Case Reports 2012;10.1136/bcr-02-2012-5756, Published XXX

Become a Fellow of BMJ Case Reports today and you can:

- Submit as many cases as you like

- Enjoy fast sympathetic peer review and rapid publication of accepted articles

- Access all the published articles

- Re-use any of the published material for personal use and teaching without further permission

For information on Institutional Fellowships contact consortiasales@bmjgroup.com

Visit casereports.bmj.com for more articles like this and to become a Fellow 